\title{
'Sound science' code draws fire
}

\section{Critics assail the US Department of the Interior's draft policy on scientific integrity.}

If there is one thing about Barack Obama's US presidency that has warmed the hearts of scientists, it is his March 2009 memo on scientific integrity. It seemed to signal a break from alleged political interference with science, and suggested that the incoming government would put sound science at the centre of policymaking. But the first draft policy on scientific integrity from a federal agency, released by the Department of the Interior (DOI) on 31 August, has drawn a storm of criticism from watchdogs including the Union of Concerned Scientists (UCS), based in Cambridge, Massachusetts.

The memo charged agencies with developing policies on scientific integrity, meant to ensure that procedures and decisions are based on solid science. (Scientific misconduct policies, already in force at several agencies, have a different aim: policing the research practices of individual scientists.) But implementing Obama's vision may be harder than expected.

In April, the DOI's research and oversight operation was catapulted into the media spotlight by the Deepwater Horizon oil spill in the Gulf of Mexico, which gave currency to independent allegations that officials at the department's Minerals Management Service - later renamed the Bureau of Ocean Energy, Management, Regulation and Enforcement (BOEMRE) - had grown cosy with the oil industry. On 28 April, a report from DOI inspector-general Mary Kendall criticized the agency for not having a comprehensive scientific integrity policy.

The DOI responded with their draft policy, open for public comment until 20 September. Among its stated objectives is protecting the public "from the effects of inaccurate information", but a sticking point for critics is a section that seems to

"Decision-makers are in a position to create far more mischief than a typical scientist would." let political appointees at the top of the agency off the hook if they alter scientific documents. The policy says that "decision-makers may be involved in editing of documents for clarification of major points to aid decision-making". This is loaded language for critics who say that it leaves the door open to political interference.

An example of interference is the case of Julie MacDonald, former deputy assistant secretary of the US Fish and Wildlife Service (FWS), part of the DOI. MacDonald resigned in $2007 \mathrm{after}$ it came to light that she had reversed findings on endangered species such as the sage grouse (Centrocercus urophasianus) when editing
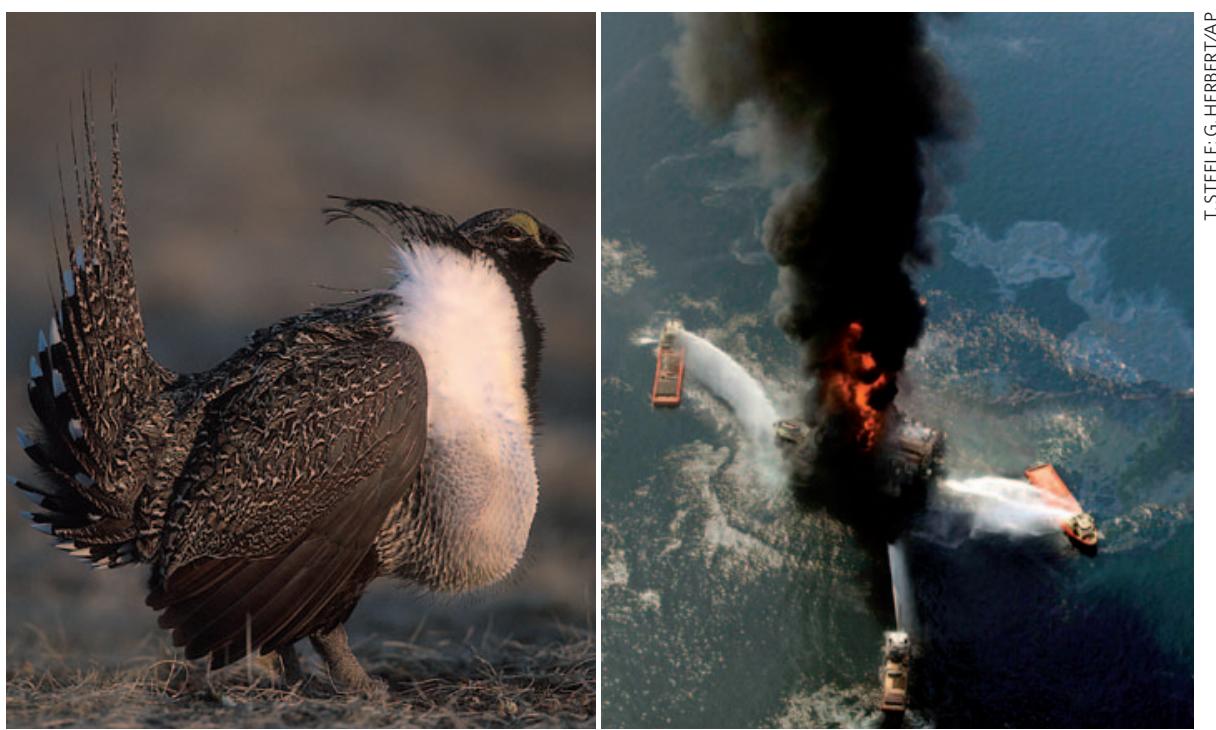

Scientific integrity shortfalls then and now: the sage grouse and the Deepwater Horizon disaster.

documents by scientists. "Decision-makers are in a position to create far more mischief than a typical scientist would," says Francesca Grifo of the UCS.

The policy also warns that "Public release of a scientific product without the required level of review or without the inclusion of appropriate disclaimers" could be considered misconduct - something that advocacy groups say could be used to force out whistle-blowers or even just scientists who circulate their work to external colleagues for comments. "What's premature release is subjective," says John Fitzgerald of the Society for Conservation Biology in Washington DC.

Andrew Eller, a former FWS biologist who in 2004 brought a separate complaint about the use of flawed data, says that he doesn't believe the draft policy is sufficient to restrain managers from distorting information. Eller was fired from the FWS but reinstated in 2005 after his complaint was upheld. "The policy as proposed would not have prevented the problems I encountered," he says.

Policy-makers may be outside the purview of the integrity policy, but the document does stipulate disciplinary actions - including possible dismissal - for scientific staff who deviate from it. The policy includes not only the usual prohibition of plagiarism, fabrication and falsification, but also a Code of Scientific Conduct.
The advocacy group Public Employees for Environmental Responsibility, in Washington DC, has identified the code as virtually identical to one put out in a DOI press release in 2002 during George W. Bush's administration.

The DOI has emphasized that its policy is a draft, and it is ready to accept criticism. "We're looking to solicit comment from the scientific community to improve it," says Kendra Barkoff, press secretary for the DOI. She says that the policy will be worked on by Alan Thornhill, science adviser to BOEMRE, and Marcia McNutt, director of the US Geological Survey - the only section of the DOI found by the inspector-general to have a comprehensive integrity policy.

Nick Steneck, a research ethicist at the University of Michigan in Ann Arbor, says DOI officials are probably hampered by a lack of direction from the White House's Office of Science and Technology Policy, which was charged in the Obama memo with providing recommendations for action on scientific integrity by July 2009. The office's director, John Holdren, said in a blog post on 18 June that the process of formulating a policy was more "laborious and time-consuming" than had been expected. Now it seems that the DOI has become a test case for the government. "They clearly are setting the precedent for how an agency is responding to that memo," says Steneck.

Eugenie Samuel Reich 